\title{
RECYCLED PLASTIC USED IN CONCRETE PAVER BLOCK
}

\author{
Ganesh Tapkire ${ }^{1}$, Satish parihar ${ }^{2}$, Pramod Patil $^{3}$, Hemraj R Kumavat ${ }^{4}$ \\ ${ }^{I}$ P.G. Student, Dept of civil Engineering NRI Institute of Research \& Technology, Bhopal, Madhya Pradesh India \\ ${ }^{2} \mathrm{HOD}$, Dept of civil EngineeringNRI Institute of Research \& Technology, Bhopal, Madhya Pradesh India \\ ${ }^{3}$ P.G. Student, Dept of civil Engineering SSBTCOE Bambhori, Jalgaon \\ ${ }^{4}$ Assistant Professor, Civil Department,RCPIT Shirpur, Maharashtra
}

\begin{abstract}
In this paper Recycled plastic aggregate used in various proportion in concrete mix and check there sutbility .Amount of waste plastic being accumulated in 21st centuries has created big challenges for their disposal, thus obliging the authorities to invest in felicitating the use of waste plastic coarse aggregate in a concrete is fundamental to the booming construction industry. Disposal of plastic waste in an environment is considered to be a big problem due to its very low biodegradability and presence in large quantities. In recent time use of such, Industrial wastes from plastic bottles, pallets, carry bags; polypropylene (PP) and polyethylene Terepthalate (PET) were studied as alternative replacements of a part of the conventional aggregates of concrete. If plastic wastes can be mixed with the concrete mass in some quantity or in some form, without affecting the fundamental and other properties or slight negotiation in strength the strength of concrete. Industrial wastes from polypropylene $(P P)$ and polyethylene Terepthalate (PET) were studied as alternative replacements of a part of the conventional aggregates of concrete. Three replacement levels.10\%, 20\%, 30 by Weight of aggregates were used for the preparation of the concrete.
\end{abstract}

Keywords: PA: Plastic Aggregate: Polyethylene Terephthalate, LDPE : Low Density Polyethylene HDPE : High Density Polyethylene, RCA Recycled Plastic Aggregate.PaverBlock. $* * *$

\section{INTRODUCTION}

The wastes plastic in household is large and increases with time. In each country the waste composition is different, since it is affected by socioeconomic characteristics, consumption patterns and waste management programs, but generally the level of plastics in waste composition is high. The largest component of the plastic waste is polyethylene, followed by polypropylene, polyethylene Terepthalate and polystyrene. The large volume of materials required for construction is potentially a major area for the reuse of waste materials. Recycling in concrete has advantages since it is widely used and has a long service life, which means that the waste is being removed from the waste stream for a long period. Because the amount of mineral aggregates required in concrete is large, the environmental benefits are not only related to the safe disposal of bulk waste, but also to the reduction of environmental impacts arising from the extraction of aggregates.

\subsection{Definition of Plastic}

A material which contains one or more number of polymers having large molecular weight." Solid in its finished state or same state will manufacturing or processing into finished articles is known as Plastic. Looking to the global issue of environmental pollution by post-consumer plastic waste, research efforts have been focused on consuming this waste on massive scale in efficient and environmental friendly manner. Researchers planned to use plastic waste in form of concrete ingredient as the concrete is second most sought material by human beings after water. The use of postconsumer plastic waste in concrete will not only be its safe disposal method but may also improve the concrete properties like tensile strength, chemical resistance, drying shrinkage and creep on short and long term basis.

Why The Plastics:- Polymers have a number of vital properties, which exploited alone or together, make a significant and expanding contribution to constructional needs.

- Durable and corrosion resistant.

- Good Insulation for cold, heat and sound saving energy.

- It is economical and has a longer life.

- Maintenance free (such as painting is minimized)

- Hygienic and clean

- Ease of processing / installation

- Light weight

\section{PROPOSED METHODOLOGY}

Recycled Plastic Aggregate (RPA) in concrete is acceptable there are for the making of concrete used coarse aggregate having size $10 \mathrm{~mm}$, natural river sand used for making a concrete and plastic aggregate used in concrete. Test carried out on these aggregate density, and sieve analysis., water absorption, all these test conduct on Recycled plastic aggregate sample

conventional aggregate and compressive strength of concrete at 10\%, 20\%, 30 replacement of plastic aggregate in concrete. 


\subsection{Material}

a) Cement b) coarse aggregate c) Fine aggregate(sand), d) Recycled Plastic aggregate size less than $10 \mathrm{~mm} . \mathrm{e})$ Water.

a) Cement :- Ordinary Portland Cement of 43-grade was used as it satisfied the requirements of IS: 269- 1969 and results have been tabulated in table.

Table.1

\begin{tabular}{|l|l|}
\hline Properties of cement \\
\hline Specific gravity & 3.15 \\
\hline Consistency & $33 \%$ \\
\hline Fineness & 7.5 \\
\hline InitialSetting Time & 45 minute \\
\hline FinalSetting Time & 480 \\
\hline
\end{tabular}

b) Coarse Aggregate:- coarse aggregate shall comply with the requirement of IS 383 as for as possible crushed Aggregate shall be used for ensuring adequate durability. The aggregate used for production of block shall beSound and free from soft and honeycombed particle the nominal maxi size of coarse aggregate used in Production of paver block shall be $10 \mathrm{~mm}$.

c) Fine aggregate:- Fine aggregate shall conform to requirement of IS 383 For river sand

Table .2

\begin{tabular}{|l|l|l|l|}
\hline \multirow{2}{*}{ Test } & \multicolumn{3}{|l|}{ Types of Aggrgate } \\
\cline { 2 - 4 } & Coarse & Fine & Plastic \\
\hline Specific Gravity & 2.60 & 2.66 & 1.04 \\
\hline Water Absorption & $0.85 \%$ & $1.0 \%$ & Nil \\
\hline Density $(\mathrm{Kg} / \mathrm{m} 3)$ & $1865 \mathrm{~kg} / \mathrm{M}^{3}$ & $1080 \mathrm{Kg} / \mathrm{M}^{3}$ & $640 \mathrm{Kg} / \mathrm{M}^{3}$ \\
\hline Moisture content & Nil & $1 \%$ & Nil \\
\hline
\end{tabular}

d) Water: - The water used for mixing concrete mix should be potable drinking water having PH 6 TO 8 .

Table .3

\begin{tabular}{|l|l|}
$\begin{array}{l}\text { As per design M40 Grade Material } \\
\text { Requirement for } 1 \mathbf{M}^{\mathbf{3}}\end{array}$ \\
\hline Material & Quantity in kg \\
\hline Cement & 350 \\
\hline Sand & 896 \\
\hline Aggregate & 1140 \\
\hline Water & 175 lit \\
\hline
\end{tabular}

\subsection{Design Mix}

As per design mix M40 grade given table shows the quantity of material for this reference to take the material quantity for 6 Nos cube each proportion material required.
Table 4

\begin{tabular}{|l|l|l|l|l|}
\hline \multicolumn{5}{|l|}{ Material proportion in weight batching(All weight in } \\
\hline Material & $0 \%$ & $10 \%$ & $20 \%$ & $30 \%$ \\
\hline Cement & 10 & 10 & 10 & 10 \\
\hline Sand & 26 & 26 & 26 & 26 \\
\hline Aggregate Proportion (Kg) \\
\cline { 1 - 3 } Regular & \multirow{3}{*}{33} & 29.7 & 26.4 & 23.1 \\
\cline { 3 - 5 } Plastic & 3.3 & 6.6 & 9.9 \\
\cline { 3 - 5 } Total & 33 & 33 & 33 \\
\hline
\end{tabular}

After the casting the cube remove from the mould after $24 \mathrm{hrs}$ and than put the curing tank for curing of 14 days and 28 days after the curing completed remove from curing tank and dry to normal atmosphere atlest $2 \mathrm{hrs}$ for the surface dry then to check it for compression testing machine get the result.

Table 5

\begin{tabular}{|c|c|c|c|c|}
\hline $\begin{array}{l}\text { Plastic } \\
\text { Aggregate } \\
\text { in \% }\end{array}$ & $\begin{array}{l}14 \text { days } \\
\text { cstrength }\end{array}$ & $\begin{array}{l}\text { Avg } \\
\text { strength }\end{array}$ & $\begin{array}{l}28 \text { days } \\
\text { estrength }\end{array}$ & $\begin{array}{l}\text { Avg } \\
\text { strength }\end{array}$ \\
\hline \multirow{3}{*}{0,00} & 28.80 & \multirow{3}{*}{28.87} & 39.50 & \multirow{3}{*}{41.10} \\
\hline & 27.80 & & 42.00 & \\
\hline & 30.00 & & 41.80 & \\
\hline \multirow{3}{*}{10,00} & 26.80 & \multirow{3}{*}{27.70} & 39.00 & \multirow{3}{*}{40.07} \\
\hline & 29.00 & & 40.30 & \\
\hline & 27.30 & & 40.90 & \\
\hline \multirow{3}{*}{20,00} & 26.00 & \multirow{3}{*}{26.90} & 38.70 & \multirow{3}{*}{38.97} \\
\hline & 27.90 & & 39.60 & \\
\hline & 26.80 & & 38.60 & \\
\hline \multirow{3}{*}{30,00} & 25.00 & \multirow{3}{*}{25.43} & 37.60 & \multirow{3}{*}{37.77} \\
\hline & 26.50 & & 38.60 & \\
\hline & 24.80 & & 37.10 & \\
\hline
\end{tabular}

In above investigation it is found that the optimum plastic aggregate was $10 \%$ to $20 \%$ by weight of coarse aggregate from the test result it was observed that the compressive strength of concrete mix satisfy the I.S.456-2000Table no.11 (Clauses 16.1 Md 16.3) acceptanc criteriacomparison of concrete.

Table 6

\begin{tabular}{|c|c|c|}
\hline $\begin{array}{l}\text { Grade } \\
\text { of } \\
\text { concrete }\end{array}$ & $\begin{array}{l}\text { Mean of the group of Non- } \\
\text { overlapping consective test } \\
\text { resultin N/mm2 }\end{array}$ & $\begin{array}{l}\text { Individual } \\
\text { test.Result in } \\
\mathrm{N} / \mathrm{mm} 2\end{array}$ \\
\hline M10 & $\begin{array}{l}(\mathrm{fck}+3 \mathrm{~N} / \mathrm{mm} 2 \quad \text { ') or } \\
(\mathrm{fck}+0825 \mathrm{XS} . \mathrm{D} .) \text { which ever is } \\
\text { greater }\end{array}$ & $\begin{array}{l}\text { Greater than } \\
\text { or Equal to } \\
\text { fck } \\
\end{array}$ \\
\hline $\begin{array}{l}\text { M20 } \\
\text { OR } \\
\text { ABOVE }\end{array}$ & $\begin{array}{ll}(\mathrm{fck} \quad+ & 4 \mathrm{~N} / \mathrm{mm} 2) \text { or } \\
(\mathrm{fck}+0825 \mathrm{XS} . \mathrm{D} .) & (\text { which ever } \\
\text { is greater } & \end{array}$ & $\begin{array}{l}\text { Greater than } \\
\text { or Equal to } \\
\text { fck } \\
\mathrm{N} / \mathrm{mm} 2\end{array}$ \\
\hline
\end{tabular}




\section{CONCLUSIONS}

a) The concrete consist of cement, sand, Aggregate and water. Out of which the aggregate percentage is 60 to $70 \%$ in concrete and from the above observation, it is computed to use the $20 \%$ Recycled plastic aggregate in concrete which does not affect the properties of concrete.

b) From the above observation it is possible to use the plastic in concrete mix up to $20 \%$ weight of coarse aggregate.

c) Looking in to above aspect we come to the conclusion that plastic can be in cement concrete mix increase the $\%$ in plastic to decrease the strength of concrete.

d) By using the plastic in concrete mix to reduces the weight of cube up $15 \%$.

e) From the above observation it is possible to use the plastic in concrete and bonding admixture in concrete and also increase the $\%$ of plastic in concrete.

f) Lastly, we strongly conclude the use of Recycled plastic aggregate in concrete which is the best option for the disposal of plastic \& ultimately reduces the plastic pollution in the Environment.

\section{REFERENCES}

[1]. Madam Mohan Reddy, K, Ajitha .B, and Bhavani .R, "Melt-Densified Post Consumer Recycled Plastic Bags Used as Light Weight Aggregate in Concrete"," International Journal of Engineering Research and Applications (IJERA) ISSN: 2248-9622 Vol. 2, Issue4, July-August 2012, pp.1097-1101.

[2]. V. Kasselouri - Rigopoulou, S. Gavela, S. Kolias "Use Of Polymeric Wastes in The Concrete Production" Polymers in concrete: a vision for the 21st century, Cement \& Concrete Composites 21: (1999) 449-452.

[3]. Baboon Rai, S. Tabin Rushad, Bhavesh Kr, and S. K. Duggal "Research Article Study of Waste Plastic Mix Concrete with Plasticizer" International Scholarly Research Network ISRN Civil Engineering Volume 2012, Article ID 469272, 5 pages doi:10.5402/2012/469272 2005.

[4]. Manual on Cement Concrete \& Aggregates Australia Use of Recycled Aggregates in Construction May 2008Removal and Reuse of Hardened Concrete (ACI 555RAmerican Concrete Institute.

[5]. S. Gavela, C. Karakosta , C. Nydriotis , V. KaselouriRigopoulou , S. Kolias, P. A. Tarantili , C. Magoulas , D. Tassios and A. Andreopoulos "A Study Of Concretes Containing Thermoplastic Wastes As Aggregates.

[6]. L. R. Bandodkar, A. A. Gaonkar, N. D. Gaonkar, \& Y. P. Gauns " Pulverised PET Bottles as Partial Replacement for Sand" International Journal of Earth Sciences and Engineering 1009 ISSN 0974-5904, Volume 04, No 06 SPL, October 2011, pp. 1009-1012

[7]. Dr. Prahallada M.C and Dr. Prakash K.B "Strength and Workability Characteristicsof Waste Plastic Fibre Reinforced Concrete Produced From Recycled Aggregates" International Journal of Engineering Research and Applications (IJERA) ISSN: 2248-962

[8]. L. R. Bandodkar, A. A. Gaonkar, N. D. Gaonkar, \& Y. P. Gauns "Pulverised PET Bottles as Partial Replacement for Sand" International Journal of Earth Sciences and
Engineering 1009 ISSN 0974-5904, Volume 04, No 06 SPL, October 2011, pp. 1009-1012.

[9]. Dr. Prahallada M.C and Dr. Prakash K.B "Strength and Workability Characteristicsof Waste Plastic Fibre Reinforced Concrete Produced From Recycled Aggregates" International Journal of Engineering Research and Applications (IJERA) ISSN: 2248-9622.

[10]. V. Vytlacilov "The fibre reinforced concrete with using recycled aggregates" International Journal Of Systems Applications, Engineering \& Development Issue 3, Volume 5,2011

\section{BIOGRAPHIES}

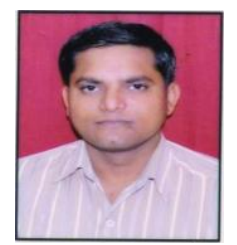

Ganesh v.Tapkire Completed B.E. in civil Engineering 2008 and M-Tech appear in Building Construction \&Technology in RGPV University Bhopal (MP).presented and Publish paper 02 Reaserch paper in Natinal conference and 01 Internatinal Journal along with publication author had attened 05 workshop sponsoerd by ISTE. Have two years site experience in NH-3 Pimpalgaon-dhule BOT Project. From last two year assistant professor in civil Engineering department in R.C.Patel.Instute of Techonology Shirpur

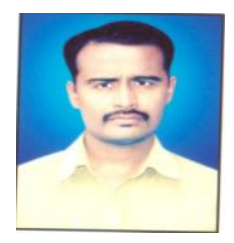

Prof. Satish Parihar Pramod S.Patil Completed B.E. in civil Engineering 2009 and ME appear in Enviormental science\& Engineering North Maharashtra UniversityJalgaon.presented and Publish paper 02 Reaserch paper in Natinal conference and 01 Internatinal Journal along with publication author had attened 05 workshop sponsoerd by ISTE. From last two year assistant professor in civil Engineering department in R.C.Patel.Instute of Techonology Shirpur 